\title{
Size Polymorphism and Fluctuating Asymmetry of Artemia (Branchiopoda: Anostraca) Populations from the Crimea
}

\author{
Nickolai V. Shadrin* and Elena V. Anufriieva \\ A.O. Kovalevsky Institute of Marine Biological Research RAS \\ 2 Nakhimov ave., Sevastopol, 299011, Russia
}

Received 11.11.2016, received in revised form 23.12.2016, accepted 17.01.2017

Fluctuating asymmetry (FA) of animals as a measure of ontogenetic stability is widely used in environmental bioindication. Environmental stress leads to increased levels of FA within populations. Artemia (Anostraca) is among the most primitive and ancient groups of crustaceans, inhabiting hypersaline waters worldwide. Despite of this there are only few studies on FA in Artemia populations, showing opposite results. To assess FA we used length of the first antenna and number of furcal setae on left and right sides. In 2004-2013 the samples were collected from 10 hypersaline lakes in Crimea. Two size groups presented in the studied lakes; diploids constitute a small size group, and polyploids - a larger one. Average length in both groups significantly correlated with salinity. No one directed influence of salinity on FA was found. Manifestation of FA was different in small and large size groups. Changes in salinity can explain not more than 40-55\% of FA variability for studied traits. Parthenogenetic populations of Artemia in Crimean lakes have differences in FA manifestation, which may be explained by differences in water salinity, genetic architecture, and selective pressure against individuals with highest FA. We cannot explain the observed FA differences in studied Artemia populations.

Keywords: developmental instability, genetic differences, ploidy, salinity, selective pressure.

Citation: Shadrin N.V., Anufriieva E.V. Size polymorphism and fluctuating asymmetry of Artemia (Branchiopoda: Anostraca) populations from the Crimea. J. Sib. Fed. Univ. Biol., 2017, 10(1), 114-126. DOI: 10.17516/1997-1389-0012.

(C) Siberian Federal University. All rights reserved

* Corresponding author E-mail address: snickolai@yandex.ru 


\title{
Размерный полиморфизм \\ и флуктуирующая асимметрия \\ в крымских популяциях Artemia \\ (Branchiopoda: Anostraca)
}

\author{
Н.В. Шадрин, Е.В. Ануфриева \\ Институт морских биологических исследований \\ имени А.О. Ковалевского РАН \\ Россия, 299011, Севастополь, пр. Нахимова, 2
}

\begin{abstract}
Флуктуирующая асимметрия (ФА) животных широко используется в экологической биоиндикации в качестве показателя онтогенетической стабильности. Экологический стресс приводит к повышению уровня ФА в пределах популяиий. Представители рода Artemia (Anostraca) являются одними из самых примитивныхх и древних групп ракообразных, населяюших гиперсоленые водоемы во всем мире. Несмотря на это, существует лишь несколько исследований ФА в популяциях Arteтіа, которые показали противоположные результаты. Для оценки ФА мы использовали длину первой антенны и количество фуркальных щетинок на левой и правой сторонах. Пробы были собраны в 10 гиперсоленых озерах Крыма в 2004-2013 г2. В исследованных озерах найдены две размерные группы: диплоидные особи представляют собой малоразмерную группу и полиплоидные - большеразмерную. Средняя длина в обеих группах достоверно коррелирует с соленостью. Влияния солености на ФА обнаружено не было. Проявление ФА отличается в малоразмерной и большеразмерной группах. Изменением солености можно объяснить не более 40-55 \% изменчивости ФА исследуемых признаков. Партеногенетические популяции Arteтіа в крымских озерах имеют различия в проявлении ФА, что можно объяснить различиями в солености воды, генетической структуре и селективного давления в отношении экземпляров с самой высокой ФА.
\end{abstract}

Ключевые слова: неустойчивость развития, генетические различия, плоидность, соленость, селективное давление.

\section{Introduction}

An organism's phenotype is determined by the genes, the environment and stochastic developmental events (Strunnikov, 1989). Developmental noise - random variation in a suite of developmental factors that are the ultimate cause of subtle deviations from symmetry, including metabolic rates, concentrations of regulatory molecules, diffusion, thermal noise, and rates of cell division, cell growth and cell death, etc. (Waddington, 1957; Strunnikov, 1989; Mitton, 1993; Leamy and Klingenberg, 2005). Fluctuating asymmetry (FA) - the small, random, not directed, deviation from symmetry of bilaterally symmetrical traits is the phenotypic outcome of developmental instability - an individual inability to buffer its development against random noise (Waddington, 1942, 1957; Dongen, 2006). Less optimal environment leads to increased developmental noise; this results 
to lower developmental precision and increased FA. As a consequence, the average unsigned deviation from symmetry, to which the term FA typically refers, has achieved prominence as a measure of developmental stability or the ability of a given genotype to produce the same target phenotype with small deviations on opposite sides of the body (Zakharov, 1987; Palmer and Strobeck, 2003). Many biologists/ecologists are interested in monitoring environmental stress in populations, preferably before stress irreversibly damage populations. FA as a measure of ontogenetic stability is an important indicator of comfort (optimality) of their developmental environment (Zakharov, 1987; Palmer and Strobeck, 2003). While a variety of bioindicators exist, FA has received increasing attention in last decades. Phenomenon of FA in different groups of organisms is well known, including in different crustacean orders (Gomelyuk and Ozolinsh, 1986; Garmew et al., 1994; Shadrin and Popova, 1994; Stige et al., 2006; Ho et al., 2009; Maia et al., 2009); increased level of environmental stress was shown lead to increased levels of FA within populations. However, on other hand there is the growing body of literature questioning the value of FA as a biomonitor tool of developmental stress (Floate and Fox, 2000; Cárcamo et al., 2008).

Artemia (Anostraca) is among the most primitive and ancient groups of crustaceans (Olesen, 2009). Different species of Artemia play a dominant role in ecosystems of hypersaline waters, and often they are the only animals in these extreme biotopes (Triantaphyllidis et al., 1998; Shadrin et al., 2012). Also their role in the development of aquaculture is difficult to overestimate (Sorgeloos et al., 2001). They are currently used extensively in toxicology and pharmacology to assess the effects of various toxicants and screening of biologically active substances (Nunes et al., 2006). Despite all this there are only few studies on FA in Artemia populations (Wang et al., 1991; Boyko, 2013), which showed opposite results. Boyko found a strong significant negative correlation between salinity and FA values (Boyko, 2013). At first view it seems as a paradoxical result - the lowest FA values in a most stressful condition of highest salinity. Question arises: Is it common peculiarity for Artemia populations in different regions?

There are at least 29 hypersaline water bodies in the Crimea as Artemia sites of two bisexual species A. urmiana Gunther, 1899 (Lake Koyashskoye) and A. salina (Linnaeus, 1758) as well as parthenogenetic populations of Artemia (Shadrin et al., 2012). The aim of this communication is to present and discuss results of our study on size polymorphism and FA in Artemia populations in the Crimean hypersaline waters.

\section{Materials and Methods}

Study area

Crimea is the largest peninsula in the Black Sea (about 26.5 thousands $\mathrm{km}^{2}$ ), where the hypersaline water bodies constitute a very characteristic and peculiar habitat type (Shadrin, 2009). There are two types of them: marine origin (thalassohaline); and continental origin (athalassohaline, with a high concentration of sulfates; the athalassohaline lakes were formed in the calderas of ancient mud volcanoes). In this paper we have used the results of our multiannual study of the saline lakes in the Crimea (2004-2013), the results of which have partially been published previously (Senicheva et al., 2008; Belmonte et al., 2012; Shadrin and Anufriieva, 2013).

\section{Sampling methods}

In 2004-2013 a total of 16 samples were collected from 10 hypersaline water bodies (Table 1). Most of the water bodies are very shallow; therefore water was collected by a $5 \mathrm{~L}$ 
Table 1. Characteristics of studied water bodies and taken samples

\begin{tabular}{|c|c|c|c|c|c|c|c|}
\hline № & Study date & Lake & Coordinates & $\mathrm{S}$ & $\mathrm{T}$ & $\mathrm{N}$ & $\mathrm{n}$ \\
\hline \multicolumn{8}{|c|}{ Parthenogenetic populations } \\
\hline 1 & 07.08 .13 & Tobechikskoye, p. 1 & N4511'04”'E36¹7'59”' & 85 & 22 & - & 50 \\
\hline 2 & 07.08 .13 & Tobechikskoye, p. 2 & N4511'04”'E36¹7'59”' & 100 & 26 & - & 50 \\
\hline 3 & 09.08 .13 & Terekly-Konradskoye & N4510’41" E3313’02” & 205 & 30 & 2640 & 50 \\
\hline 4 & 09.08 .13 & Bolshoi Kipchak & N4522’09” E32³1’08”' & 145 & 34 & 1891 & 50 \\
\hline 5 & 06.08 .13 & Tobechikskoye, p. 3 & N4510’13”E3620’59”' & 175 & 30 & - & 12 \\
\hline 6 & 06.09 .12 & Chersonesskoye & N44³5’09” E3323’32” & 108 & 28 & 20480 & 50 \\
\hline 7 & 30.04 .09 & Adzhigol & N4506'27’'E35²7'53”' & 120 & 22 & 9733 & 25 \\
\hline 8 & 01.06 .12 & Chokrakskoye & N4527'50” E36¹8’42”' & 100 & 24 & 86400 & 50 \\
\hline 9 & 09.08 .12 & Bolshoi Kipchak & N4522’09” E32³1’08” & 280 & 27 & 3040 & 50 \\
\hline 10 & 28.05 .08 & Aktashskoye & N4522’43”'E3548’48” & 164 & 23 & - & 20 \\
\hline 11 & 22.08 .09 & Dzharylhatch & N4534’04” E32॰51’30” & 161 & 18 & 4760 & 20 \\
\hline 12 & 08.05 .10 & Uzunlarskoye & N4502’53” E36 06’16” & 185 & 25 & 13120 & 20 \\
\hline 13 & 23.08 .09 & Terekly-Konradskoye & N45 ${ }^{\circ} 10^{\prime} 41^{\prime \prime} \mathrm{E} 33^{\circ} 13^{\prime} 02^{\prime \prime}$ & 290 & 21 & 680 & 25 \\
\hline 14 & 16.08 .07 & Tobechikskoye & N4510’33”E36²1’00” & 182 & 30 & 19620 & 50 \\
\hline \multicolumn{8}{|c|}{$\begin{array}{c}\text { Bisexual populations } \\
\text { Artemia } \mathrm{sp.}\end{array}$} \\
\hline 15 & 05.08 .13 & Aktashskoye & N45²3’28”'E3551'54” & 130 & 30 & 240 & $50^{*}$ \\
\hline \multicolumn{8}{|c|}{ Artemia urmiana } \\
\hline 16 & 25.08 .04 & Koyashskoye & N4502’10” E36¹1’47” & 275 & 32 & 7230 & $50^{*}$ \\
\hline
\end{tabular}

№ - number of sample; $\mathrm{S}$ - salinity, g/L; $\mathrm{T}$ - temperature, ${ }^{\circ} \mathrm{C} ; \mathrm{N}-$ density, ind. $\mathrm{m}^{-3} ; \mathrm{n}$ - number of measured specimens; *50 females and 50 males.

bucket. On each sampling occasion 50-100 L of water were filtered through a $110 \mu \mathrm{m}$ meshsize plankton net and the resulting sample immediately preserved with a $4 \%$ buffered formalin solution. In situ salinity, temperature and $\mathrm{pH}$ were measured at time of sampling using a portable hand-held salinity refractometer (Kelilong WZ212) and a portable temperature/ pH meter (PHH-830).

\section{Processing of samples and FA assessment}

Abundance of animals was determined by direct counting them in a sample using an Olympus SZ-ST stereo microscope with subsequent dividing by the volume of filtered water. To assess FA we selected length of the first antenna (a) and number of furcal setae (f) on left and right sides of an animal. Measurements of body length and other parameters were made only on adult Artemia under microscope PZO Warszawa SK14 with ocular micrometer. In total 722 individuals were measured. All measured values are given in Table 2.

\section{Statistical analysis}

To analyze the animal size frequency distributions we used probability paper (Cassie, 1954). In study of FA it is necessary to distinguish FA from other types of asymmetry. For each bilateral trait the presence of directional asymmetry was tested (Shadrin et al., 2005). Significance of differences in average values of a studied parameter on left and right sides was evaluated by Student $t$-test. Both studied 
Table 2. Measured and calculated parameters on body length, length of first antenna and number of furcal setae in Artemia populations of the Crimean hypersaline waters

\begin{tabular}{|c|c|c|c|c|c|c|c|c|c|c|c|c|}
\hline \multirow{2}{*}{ № } & \multicolumn{5}{|c|}{ First antenna length } & \multicolumn{5}{|c|}{ Furcal setae number } & \multicolumn{2}{|c|}{ Body length } \\
\hline & AV & $\mathrm{CV}$ & $\mathrm{PA}$ & FAVa & FAV'a & AV & $\mathrm{CV}$ & PA & FAVf & FAV'f & $\mathrm{L}$ & $\mathrm{CV}$ \\
\hline \multicolumn{13}{|c|}{ Parthenogenetic populations } \\
\hline 1 & 1.1 & 8.98 & 66 & 0.09 & 0.08 & 10.90 & 41.10 & 72 & 1.83 & 0.17 & 10.68 & 10.6 \\
\hline 2 & 1.0 & 16.36 & 70 & 0.12 & 0.12 & 13.39 & 39.30 & 86 & 3.56 & 0.27 & 8.67 & 11.0 \\
\hline 3 & 0.7 & 19.69 & 80 & 0.08 & 0.12 & 0.67 & 90.30 & 36 & 1.06 & 2.33 & 12.08 & 8.76 \\
\hline 4 & 4.6 & 57.42 & 58 & 0.08 & 0.02 & 4.56 & 31.50 & 68 & 1.59 & 0.35 & 9.77 & 9.39 \\
\hline 5 & 0.7 & 20.86 & 25 & 0.05 & 0.07 & 10.42 & 39.70 & 92 & 1.60 & 0.15 & 7.71 & 15.5 \\
\hline 6 & 1.1 & 14.96 & 25 & 0.08 & 0.07 & 12.20 & 27.90 & 59 & 2.14 & 0.18 & 10.22 & 8.56 \\
\hline 7 & 1.0 & 9.00 & 45 & 0.04 & 0.04 & 5.72 & 28.20 & 87 & 1.82 & 0.32 & 10.50 & 6.89 \\
\hline 8 & 0.5 & 7.76 & 68 & 0.09 & 0.18 & 2.73 & 45.70 & 60 & 1.43 & 0.53 & 10.53 & 5.67 \\
\hline 10 & 1.3 & 95.23 & 65 & 0.06 & 0.05 & 1.00 & 123.8 & 10 & 1.00 & 1.00 & 8.69 & 8.05 \\
\hline 11 & 1.5 & 102.0 & 80 & 0.05 & 0.03 & 2.00 & 99.20 & 40 & 1.13 & 0.56 & 8.28 & 6.57 \\
\hline 12 & 0.2 & 244.2 & 55 & 0.04 & 0.30 & 0.15 & 156.7 & 30 & 1.00 & 6.67 & 10.67 & 4.02 \\
\hline 13 & 0.7 & 6.32 & 80 & 0.03 & 0.04 & 0.34 & 7.00 & 88 & 1.00 & 2.94 & 9.72 & 8.40 \\
\hline 14 & 1.9 & 30.03 & 76 & 0.22 & 0.11 & 4.00 & 39.80 & 64 & 1.13 & 0.28 & 11.63 & 21.9 \\
\hline \multicolumn{13}{|c|}{$\begin{array}{c}\text { Bisexual populations } \\
\text { Artemia } \text { sp. }\end{array}$} \\
\hline $15_{\mathrm{m}}$ & 0.7 & 21.13 & 80 & 0.05 & 0.07 & 9.00 & 38.90 & 83 & 2.28 & 0.25 & 7.15 & 12.89 \\
\hline $15_{\mathrm{f}}$ & 0.4 & 17.38 & 56 & 0.06 & 0.13 & 9.05 & 38.90 & 83 & 2.31 & 0.23 & 6.35 & 9.61 \\
\hline \multicolumn{13}{|c|}{ Artemia urmiana } \\
\hline $16_{\mathrm{m}}$ & 1.0 & 9.77 & 92 & 0.11 & 0.11 & 0.98 & 63.51 & 83 & 1.03 & 1.05 & 11.82 & 0.09 \\
\hline $16_{\mathrm{f}}$ & 0.7 & 8.23 & 34 & 0.03 & 0.04 & 0.76 & 54.60 & 82 & 1.00 & 1.32 & 10.07 & 0.07 \\
\hline
\end{tabular}

№ - number of water body from table 1; AV - average value, mm; CV - coefficient of variation, \%; PA - part of asymmetrical individuals, \%; FAVa - absolute average unsigned deviation from symmetry in first antenna length, $\mathrm{mm}$; FAV'a - relative average unsigned deviation from symmetry in first antenna length; FAVf - absolute average unsigned deviation from symmetry in furcal setae number; FAV'f - relative average unsigned deviation from symmetry in furcal setae number; $\mathrm{L}$ - body length, $\mathrm{mm}$; $\mathrm{m}$ - male; $\mathrm{f}$ - female.

traits did not demonstrate directed asymmetry. That's why we used two equations to evaluate FA (Palmer and Strobeck, 2003; Shadrin et al., 2005):

$\mathrm{FAV}=\left(\sum\left|\mathrm{X}_{l i}-\mathrm{X}_{r i}\right|\right) / \mathrm{n}$,

where FAV - absolute average unsigned deviation from symmetry, $\mathrm{X}_{l i}$ and $\mathrm{X}_{r i}-$ trait on left and right sides, $\mathrm{n}$ - total number of individuals.

$\mathrm{FAV}^{\prime}=\left(\sum 2\left|\mathrm{X}_{l i}-\mathrm{X}_{r i}\right| /\left(\mathrm{X}_{l i}+\mathrm{X}_{r i}\right)\right) / \mathrm{n}$, where FAV' - relative average unsigned deviation from symmetry (a convenient dimensionless index of FA).

Portion of asymmetrical individuals in a population ( $\%$ ) was estimated as

$\mathrm{PA}=100 \% \mathrm{n}_{a s} / \mathrm{n}$,

where $\mathrm{n}_{a s}$ - number of asymmetrical individuals.

For pairs of traits, we determined whether the frequency of their asymmetry co-occurrence was a random or non-random event (Shadrin and Anufriieva, 2013). For a random event the 
frequency of co-occurrence was calculated as the product of the frequencies of asymmetrical individuals on $1^{\text {st }}$ and $2^{\text {nd }}$ traits $(\mathrm{T})$, it was compared to an observed value of the frequency of $1^{\text {st }}$ and $2^{\text {nd }}$ trait asymmetry co-occurrence $(\mathrm{O})$. If $\mathrm{O} \approx \mathrm{T}$, we made the conclusion that their cooccurrence was a random event. Average values, standard deviations, coefficients of variation $(\mathrm{CV})$, parameters of regression equations and correlation coefficients (R) were calculated in Excel; the confidence level of the correlation coefficients (p) was determined from the table of Muller et al. (1979). Selection of a best approximated equation was made from available in Excel, according highest $\mathrm{R}^{2}$.

\section{Results}

\section{Parthenogenetic populations}

Size distribution. Using probability paper for total data set (Table 2) and for some salinity intervals we found that there were at least two size groups among adult parthenogentic Artemia females. As an example, the size distribution in the salinity interval $145-205 \mathrm{~g} / \mathrm{L}$ is given in Fig. 1. Probability paper analysis showed that in this interval the average size of a small form was $9.1 \mathrm{~mm}$ and $12 \mathrm{~mm}$ of the larger form. Samples of $1,2,4,5,6,7,8,10,11$ formed the $1^{\text {st }}$ size group (small), samples of 3, 9, 12, 13, 14 - the $2^{\text {nd }}$ (large) group. Average length in both groups significantly correlated with salinity (Fig. 2), and may be approximated for $1^{\text {st }}$ group $(\mathrm{R}=-0.766$, $\mathrm{p}=0.01)$ :

$\mathrm{L}_{1}=12.791-0.026 \mathrm{~S}$,

where $\mathrm{L}_{1}$ - length of $1^{\text {st }}$ group (mm), $\mathrm{S}$ - salinity, $\mathrm{g} / \mathrm{L}$, and for $2^{\text {nd }}$ group $(\mathrm{R}=-0.822, \mathrm{p}=0.04)$ :

$\mathrm{L}_{2}=14.788-0.018 \mathrm{~S}$,

where $\mathrm{L}_{2}-$ length of $2^{\text {nd }}$ group ( $\left.\mathrm{mm}\right)$.

Temperature and population density did not significantly influence length in both groups.

Number of furcal setae. No correlation between body length and number of setae was found. There is the only insignificant trend of a negative salinity influence on number of furcal setae (Nf) in whole data set (Table 2) and in both groups. Salinity, temperature and population density did not significantly influence this parameter. Taking into account number of furcal setae all samples fall into two separated groups: one group with average number of furcal setae had average 11.33 and $\mathrm{CV}=0.114$ (samples 1,2 , 5,6 ), other - average 2.32 and $\mathrm{CV}=0.825$ (all other samples). Difference in those groups was significant $(p=0.001)$. Sample composition of

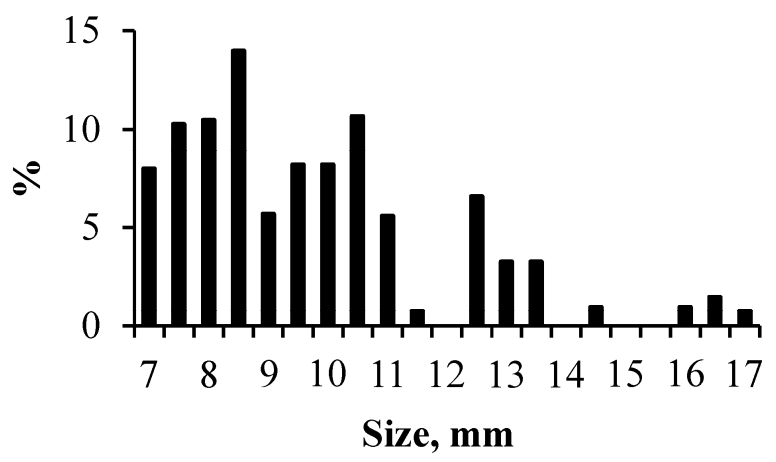

Fig. 1. Frequency the animal size distribution in the parthenogenetic Artemia populations in the Crimea under salinity $145-205 \mathrm{~g} / \mathrm{L}$ 


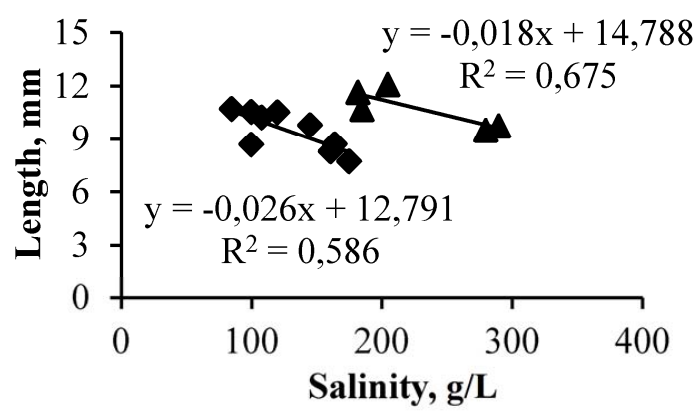

Fig. 2. Average body length (mm) of parthenogenetic Artemia in the Crimean populations and salinity (g/L): A for $1^{\text {st }}$ size group; $\mathrm{B}$ - for $2^{\text {nd }}$ size group

those two groups was not the same as for body length.

In the small size group there was the only negative insignificant trend between FAVf (absolute average unsigned deviation from symmetry) and salinity. No directed trend was observed in $2^{\text {nd }}$ group. Average FAVf was 1.789 $(\mathrm{CV}=0.420)$ in $1^{\text {st }}$ group and $1.066(\mathrm{CV}=0.630)-$ in $2^{\text {nd }}$ group. Average values of these groups were significantly different $(p=0.05)$.

Relative average unsigned deviation from symmetry (FAV'f) demonstrated insignificant positive relation with salinity only in $1^{\text {st }}$ group. Average value of FAV'f was $0.392(\mathrm{CV}=0.693)$ in $1^{\text {st }}$ group and $2.465(\mathrm{CV}=1.039)$ in $2^{\text {nd }}$ one. Percent of asymmetrical animals on this trait was close in both groups. Percent of asymmetrical animals negatively correlated with FAV'f: $(\mathrm{R}=0.874, \mathrm{p}=0.001)$ in $1^{\text {st }}$ group and in $2^{\text {nd }}$ one the trend was insignificant. Proportion FAVf/CVf increased with a salinity increase $(\mathrm{R}=0.670$, $\mathrm{p}=0.001)$; this may indicate, probably, that a FA contribution into total $\mathrm{Nf}$ variability increased under higher salinity.

First antenna length. Salinity, temperature, body length and population density didn't significantly correlate with length of first antenna and its variability (CV) in whole totality of the samples (Table 2) as well as in both groups. Portion of asymmetrical individuals in a population had not any significant correlation with salinity; in average this portion was $56.89 \%(\mathrm{CV}=0.35)$ in $1^{\text {st }}$ group and $75.20 \%(\mathrm{CV}=0.16)$ in $2^{\text {nd }}$ one. $1^{\text {st }}$ antenna length in Lake Bolshoi Kipchak was much longer than in all other cases.

FAVa had significant positive correlation with average first antenna length in the $2^{\text {nd }}$ group ( $\mathrm{R}=0.863, \mathrm{p}=0.007)$, but no such correlation presented in the $1^{\text {st }}$ group. Absolute average unsigned deviation from symmetry (FAVa) did not demonstrate significant correlation with salinity, temperature, and population density. Relative average unsigned deviation from symmetry (FAV'a) had significant negative correlation with salinity in $2^{\text {nd }}$ group $(\mathrm{R}=0.887, \mathrm{p}=0.006)$ :

FAV'a $=4.568 \mathrm{e}^{-0.018 \mathrm{~s}}$,

where FAV'a-relative average unsigned deviation from symmetry.

In $1^{\text {st }}$ group we did not observe this strong trend (Fig. 3), there was negative insignificant trend up salinity to $145 \mathrm{~g} / \mathrm{L}(\mathrm{R}=0.644, \mathrm{p}=0.07)$, and in $2^{\text {nd }}$ one - significant positive correlation $(\mathrm{R}=0.932, \mathrm{p}=0.04)$ :

$\mathrm{FAV}^{\prime} \mathrm{a}=0.002 \mathrm{~S}-0.226$.

Proportion $\mathrm{FAVa} / \mathrm{CVa}$ negatively correlated with salinity $(\mathrm{R}=-0.518, \mathrm{p}=0.05)$; FAVa 


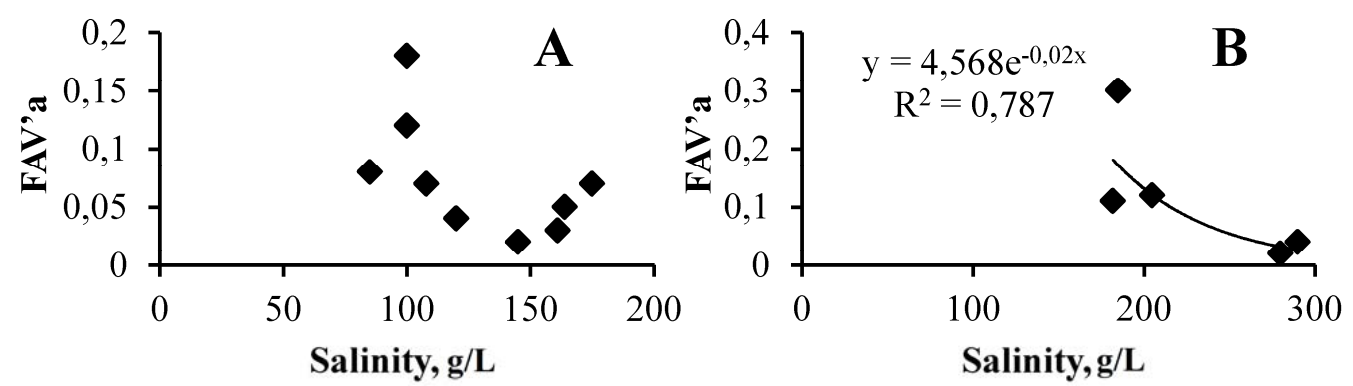

Fig. 3. Relative average unsigned deviation from symmetry (FAV'a) in length of first antenna and salinity: A - for $1^{\text {st }}$ size group; $\mathrm{B}-$ for $2^{\text {nd }}$ size group

contribution into total variability decreased at higher salinity.

Relations between measurements of FA for two traits. Calculations showed that co-occurrence of asymmetry of both traits in single individual is a random event; in all samples calculated and the observed frequencies of co-occurrence had differences only $0.5-5 \%$. If both traits were asymmetric in the individuals there was no any correlation between levels of asymmetry in both traits in a sample. The correlation between FAV'f and FAV'a was significant ( $R=0.698, p=0.005)$. The proportion FAV'f/FAV'a significantly correlated with salinity $(\mathrm{R}=0.775, \mathrm{p}=0.001)$. We also used an integral metric taking the average relative values for both studied parameters (FAV'f + FAV'a) / 2; it significantly increased with a salinity increase $(R=0.639, p=0.001)$.

\section{Bisexual population of Artemia sp.}

Sexual differences. Table 2 demonstrates that a part of asymmetrical individuals in males is 1.5-1.7 times higher than in females under different salinities. FAVa is same value in males and females at $130 \mathrm{~g} / \mathrm{L}$, but at $280 \mathrm{~g} / \mathrm{L}$ FAVa in males was at 3.5 times higher than in females. This may be determined by genetic differences of populations. FAV'a in females was about 2 times higher at $130 \mathrm{~g} / \mathrm{L}$, but at $280 \mathrm{~g} / \mathrm{L}$ this index was higher about 3 times in males. For furca there were no significant differences between males and females for all indexes. All measures of FA in bisexual populations were in same range as for parthenogenetic populations.

\section{Discussion}

Our data showed that parthenogenetic Artemia in the Crimean lakes cannot be assumed as a single morph; we observed polymorphism two or more clearly different phenotypes (in size and other parameters) exist. Previous study showed that parthenogenetic Artemia populations in Crimea have individuals with different ploidy; populations differ from each other on proportions of individuals with different levels of their ploidy (Mitrofanov et al., 1982). Polyploids in Artemia have larger cysts and body size at maturity than diploids (Amat, 1980; Zhang and King, 1993) as well as less manifested FA (Wang et al., 1991). It was found that in the different Crimean lakes there are cysts both diploid and polyploid strains of parthenogenetic Artemia; cysts of only diploid strains (size 234-254 $\mu \mathrm{m}$ ) were found in 3 lakes, only poliploid strains (size $284 \mu \mathrm{m}$ ) - in one lake, and both strains - in two lakes (Shadrin et al., 2015). All this, as well as our study of body length and two bilateral traits, are arguments that parthenogenetic populations in Crimean lakes have differences in genetic architecture; this may cause differences in FA manifestation. The found 
morphotypes demonstrated different responses on salinity including FA. Conclusions about patterns of FA variations may be seriously hampered by the impact of trait size and genetic variations (Palmer and Strobeck, 2003). An increased level of environmental stress may lead to FA increase within Artemia populations. There is the only general trend, however, the high significant differences $(\mathrm{p}=0.05-0.0005)$ between different populations presented. As an example, in salinity range $100-120 \mathrm{~g} / \mathrm{L}$ (average $107 \mathrm{~g} / \mathrm{L}, \mathrm{CV}=0.088$ ) FAV'a fluctuated between 0.175 and 0.525 (average $0.321, \mathrm{CV}=0.462$ ). We may conclude from this example that salinity is not a main driver of the FAV'a value here. Taking into account calculated coefficients of determination $-\mathrm{R}^{2}$, changes of salinity can explain not more than $53 \%$ of FAV'f variability and $45 \%$ of FAV'a variability in total data set. It is possible to assume that there are two groups of causes leading to such interpopulation differences - genotypic differences of populations and environmental differences outside populations.

The existence of significant levels of genetic variation for $\mathrm{FA}$ is the most contentious issue of developmental stability studies (Mpho et al., 2002). Some studies have detected the significant heritable variations for FA (Whitlock, 1996; Dongen, 2006), but others - non-significant heritability of FA estimates (Bjorksten et al., 2000; Mpho et al., 2002). There is little evidence for specific genes that govern FA per se; numerous studies show that FA levels in various characters are influenced by dominance and especially epistatic interactions among genes (Leamy and Klingenberg, 2005). There are some evidences that there is a relation between heterozygosity of individuals and expression of FA; FA negatively associated with genome-wide heterozygosity (Leary et al., 1984; Mitton, 1993; Zakharov, 1987; Fava and Martini, 1988; Whitlock, 1996; Pustovoit, 2010), but such relation for some traits is absent (Hosken et al., 2000; Pustovoit, 2010). In nature in polyploid individuals, as compared to diploid ones, phenotype stabilization (decrease of FA) may actually take place (Mesaroš et al., 1995; Mezhzherin and Kokodii, 2009). Polyploidization within asexual lineages, including Artemia, is associated with an increase of heterozygoty (Zhang and King, 1993). Variability in ploidy takes place in parthenogenetic populations of Artemia worldwide (Amat, 1980; Abatzopoulos et al., 1986; Zhang and King, 1993; Maniatsi et al., 2011; Maccari et al., 2013).

We may assume that only external abiotic stressing factor (salinity) and differences in genetic architecture determine FA level. However, such picture is not full. We cannot avoid a discussion of the role of natural selection. The idea, which originated with Schmalhausen (1941, 1949) and Waddington (1942, 1953, 1957), suggested that genetic variation may get canalized under stabilizing selection and released under directional selection or under stress. Perhaps, they were first to clearly see that epistatic interactions between genes can produce genetic control over genetic variability (Wagner and Altenberg, 1996). It was shown that mortality of individuals with high FA may be more than of ones with less manifested FA (Floate and Fox, 2000; Polak et al., 2002; Fréchette et al., 2003; Shadrin et al., 2005). FA may increase with growth to some age and later sharply decreases as this was observed in several species of bivalve mollusks (Shadrin et al., 2005). We may propose an acceptable explanation for these results that increasing selective pressure results in a faster loss of individuals with higher FA in a population. This may leads to situation when low FA reflects not high level of developmental stability, but high level of selective pressure against individuals with highest FA or Artemia generations in a post-reproductive age. Some data support a positive relation between polyploidy and resistance to environmental stress (Zhang 
and King, 1993) and it may also mask an increase of FA under highest salinity. Relative fitness of different cytotypes in Artemia is a function of environmental conditions; sympatric diploids and polyploids as usually respond differently to environmental changes (Zhang and King, 1993). This may lead to a change of proportion of different cytotypes in Artemia populations under high salinities, and as a result to variations in FA manifestation. It is reasonable to assume that polyploidy is an adaptive evolutionary pattern in Artemia (Maniatsi et al., 2011), and we need more understanding of this.

\section{Conclusion}

Summarizing all above we conclude that we are far from a simple explanation of observed relations between FA and salinity in Artemia populations. Parthenogenetic populations of Artemia in Crimean lakes have differences in FA manifestation, which may be explained by coupling of differences in genetic architecture, environmental factors, and increasing selective pressure, which may result in a faster loss of individuals with higher $\mathrm{FA}$ in a population. This is difficult to use directly FA of Artemia in biomonitoring of environmental condition now. The expected positive relationship between FA and stress may be altered when the stressor selectively eliminates individuals with higher FA from some population. To indicate stress in natural populations we don't need to use FA alone, only with other biological indexes. Taking into account diversity of ploidy cytotypes of Artemia, it is an excellent object to study coupling of ecological, genetic, and evolution issues of FA.

\section{Acknowledgements}

This study was partially supported by the Otto Kinne Foundation to E. V. Anufriieva. We are grateful to Mr. O. Eryomin who helped in organization and conducting of all our expeditions. We would also like to extend our thanks to Dr. F. Amat and all others who gave us the advices.

\section{References}

Abatzopoulos T.J., Kastritsis C.D., Triantaphyllidis C.D. (1986) A study of karyotypes and heterochromatic associations in Artemia, with special reference to two N. Greek populations. Genetica, 71: $3-10$

Amat F. (1980) Differentiation in Artemia strains from Spain. The Brine Shrimp Artemia, vol. I Morphology, Genetics, Radiobiology, Toxicology. Persoone G., Sorgeloos P., Roels O., Jaspers E. (eds.) Wetteren, Belgium, Universa Press, p. 19-39

Belmonte G., Moscatello S., Batogova E.A., Pavlovskaya T., Shadrin N.V., Litvinchuk L.F. (2012) Fauna of hypersaline lakes of the Crimea (Ukraine). Thalassia Salentina, 34: 11-24

Bjorksten T., David P., Pomiankowski A., Fowler K. (2000) Fluctuating asymmetry of sexual and nonsexual traits in stalk-eyed flies: a poor indicator of developmental stress and genetic quality. Journal of Evolutionary Biology, 13: 89-97

Boyko E.G. (2013) Influence of ecological factors on the growth of crustaceans from the genus Artemia in Ural and Siberian populations. Contemporary Problems of Ecology, 6: $262-267$

Cárcamo H.A., Floate K.D., Lee B.L., Beres B.L., Clarke F.R. (2008) Developmental instability in a stem-mining sawfly: can fluctuating asymmetry detect plant host stress in a model system? Oecologia, 156: 505-513

$$
-123-
$$


Cassie R.M. (1954) Some uses of probability paper in the analysis of size frequency distributions. Australian Journal of Marine \& Freshwater Research, 5: 513-522

Dongen S.V. (2006) Fluctuating asymmetry and developmental instability in evolutionary biology: past, present and future. Journal of Evolutionary Biology, 19: 1727-1743

Fava G., Martini E. (1988) Effect of inbreeding and salinity on quantitative characters and asymmetry of Tisbe holothuriae (Humes). Hydrobiologia, 167: 463-467

Floate K.D., Fox A.S. (2000) Flies under stress: a test of fluctuating asymmetry as a biomonitor of environmental quality. Ecological Applications, 10: 1541-1550

Fréchette M., Goulletquer P., Daigle G. (2003) Fluctuating asymmetry and mortality in cultured oysters Crassostrea gigas in Marennes-Oléron basin. Aquatic Living Resources, 16: 339-346

Garmew T.G., Hammond S., Mercantini A., Morgan J., Neunert C., Fornshell J.A. (1994) Morphological variability of geographically distinct populations of the estuarine copepod Acartia tonsa. Hydrobiologia, 292: 149-156

Gomelyuk V.E., Ozolinsh A.V. (1986) The use of the index of fluctuating asymmetry of bilateral structures of the crab Hemigrapsus-sanguineus for the assessment of state of the marine-environment. Biologiya Morya, 1: 68-71 (in Russian)

Ho G.W., Leung K.M., Lajus D.L., Ng J.S., Chan B.K. (2009) Fluctuating asymmetry of Amphibalanus (Balanus) amphitrite (Cirripedia: Thoracica) in association with shore height and metal pollution. Hydrobiologia, 621: 21-32

Hosken D.J., Blanckenhorn W.U., Ward P.I. (2000) Developmental stability in yellow dung flies (Scathophaga stercoraria): fluctuating asymmetry, heterozygosity and environmental stress. Journal of Evolutionary Biology, 13: 919-926

Leamy L.J., Klingenberg C.P. (2005) The genetics and evolution of fluctuating asymmetry. Annual Review of Ecology Evolution and Systematics, 36: 1-21

Leary R.F., Allendorf F.W., Knudsen K.L. (1984) Superior developmental stability of heterozygotes at enzyme loci in salmonid fishes. American Naturalist, 124: 540-551

Maccari M., Amat F., Gomez A. (2013) Origin and genetic diversity of diploid parthenogenetic Artemia in Eurasia. PLoS ONE, 8: e83348

Maia S.C.A., Molina W.F., Maia-Lima F.A. (2009) Analysis of fluctuating asymmetries in marine shrimp Litopenaeus schmitti (Decapoda, Penaeidae). Pan-American Journal of Aquatic Sciences, 4: $55-62$

Maniatsi S., Baxevanis A.D., Kappas I., Deligiannidis P., Triantafyllidis A., Papakostas S., Bougiouklis D., Abatzopoulos T.J. (2011) Is polyploidy a persevering accident or an adaptive evolutionary pattern? The case of the brine shrimp Artemia. Molecular Phylogenetics and Evolution, 58: $353-364$

Mesaroš G., Tucić B., Tucić N. (1995) Genetic diversity and multilocus structure in sexual Otiorhynchus alpicola populations (Coleoptera: Curculionidae). Biological Journal of the Linnean Society, 54: 29-41

Mezhzherin S.E., Kokodii S.V. (2009) Genetic homeostasis and developmental stability in natural populations of bisexual (Carassius auratus) and unisexual (C. gibelio) goldfishes. Cytology and Genetics, 43: 336-342 
Mitrofanov Yu.A., Ivanovskii Yu.A., Lesnikova L.N., Makarycheva A.M. (1982) Chromosome numbers and Karyotypes of some Artemia salina populations. Tsitologia i genetika (Cytology and genetics), 16: 11-14 (in Russian)

Mitton J.B. (1993) Enzyme heterozygosity, metabolism, and developmental stability. Genetica, 89: 47-66

Mpho M., Callaghan A., Holloway G.J. (2002) Temperature and genotypic effects on life history and fluctuating asymmetry in a field strain of Culex pipiens. Heredity, 88: 307-312

Müller P.H., Neuman P., Storm R. (1979) Tafeln der mathematischen Statistik. Leipzig, VEB Fachbuchverlag

Nunes B.S., Carvalho F.D., Guilhermino L.M., Stappen G.V. (2006) Use of the genus Artemia in ecotoxicity testing. Environmental Pollution, 144: 453-462

Olesen J. (2009) Phylogeny of Branchiopoda (Crustacea) - character evolution and contribution of uniquely preserved fossils. Arthropod Systematics \& Phylogeny, 67: 3-39

Palmer A.R., Strobeck C. (2003) Fluctuating asymmetry analyses revisited. Developmental instability: Causes and consequences. Polak M. (ed.) Oxford, Oxford University Press, p. 279-319

Polak M., Opoka R., Cartwright I.L. (2002) Response of fluctuating asymmetry to arsenic toxicity: support for the developmental selection hypothesis. Environmental Pollution, 118: 19-28

Pustovoit S.P. (2010) Correlation between heterozygosity and fluctuating asymmetry amplitude in pink salmon(Oncorhynchus gorbuscha). Vestnik Vserossiiskogo Obschestva Genetikovi Selektsyonerov, 14: $530-536$ (in Russian)

Schmalhausen I.I. (1941) Stabilizing selection and its role among the factors of evolution. Zhurnal Obstchei Biologii, 2: 307-354 (in Russian)

Schmalhausen I.I. (1949) Factors of evolution: the theory of stabilizing selection. Philadelphia, The Blakiston Company. (Translation from Russian by T. Dobzhansky)

Senicheva M.I., Gubelit Y., Prazukin A.V., Shadrin N.V. (2008) Phytoplankton of the Crimean hypersaline lakes. The Black Seamicroalgae:problems ofbiodiversitypreservation and biotechnological usage. Finenko Z.Z., Tokarev Yu.N., Shadrin N.V. (eds.) Sevastopol, ECOSI-Gidrofizika, p. 5-18 (in Russian)

Shadrin N.V. (2009) The Crimean hypersaline lakes: towards development of scientific basis of integrated sustainable management. Proceedings of 13th World Lake Conference, Wuhan, China, 1-5 November, 2009. http://wldb.ilec.or.jp/data/ilec/WLC13_Papers/S12/s12-1.pdf

Shadrin N.V., Anufriieva E.V. (2013) Climate change impact on the marine lakes and their crustaceans: The case of marine hypersaline Lake Bakalskoye (Ukraine). Turkish Journal of Fisheries and Aquatic Sciences, 13: 603-611

Shadrin N., Anufriieva E., Galagovets E. (2012) Distribution and historical biogeography of Artemia Leach, 1819 (Crustacea: Anostraca) in Ukraine. International Journal of Artemia Biology, 2: 30-42

Shadrin N.V., Anufriieva E.V., Amat F., Eremin O.Yu. (2015) Dormant stages of crustaceans as a mechanism of their existence in an extreme unpredictable environment of the Crimean hypersaline lakes. Chinese Journal of Oceanology and Limnology, 33 (6): 1362-1367

Shadrin N.V., Mironov S.S., Veremeeva E.V. (2005) Fluctuating asymmetry in bivalve mollusks at the sandy sublittoral near the Crimean shores (the Black Sea). Ecologia Morya, 68: 93-98 (in Russian) 
Shadrin N.V., Popova E.V. (1994) Variability of Acartia clausi in the Black Sea. Ecology and Morphology of Copepods. Ferrari F.D., Bradley B.P. (eds.) Dordrecht, Kluwer Academic Publishers, p. $179-184$

Sorgeloos P., Dhert P., Candreva P. (2001) Use of the brine shrimp, Artemia spp., in marine fish larviculture. Aquaculture, 200: 147-159

Stige L.C., Hessen D.O., Vøllestad L.A. (2006) Fitness, developmental instability, and the ontogeny of fluctuating asymmetry in Daphnia magna. Biological Journal of the Linnean Society, 88: 179-192

Strunnikov V.A. (1989) Third variability. Priroda, 2: 17-27 (in Russian)

Triantaphyllidis G., Abatzopoulos T., Sorgeloos P. (1998) Review of the biogeography of the genus Artemia (Crustacea, Anostraca). Journal of Biogeography, 25: 213-226

Waddington C.H. (1942) Canalization of development and the inheritance of acquired characters. Nature, 150: 563-565

Waddington C.H. (1953) Genetic assimilation of an acquired character. Evolution, 7: 118-126

Waddington C.H. (1957) The strategy of the genes. London, Allen and Unwin

Wagner G.P., Altenberg L. (1996) Perspective: Complex adaptations and the evolution of evolvabilty. Evolution, 50: 967-976

Wang K.X., Cai J.N., Li J.Y. (1991) Clonal and chromosome study of parthenogenetic brine shrimp (Artemia parthenogenetica) from north China. Oceanologia et Limnologia Sinica, 22: 1-8

Whitlock M. (1996) The heritability of fluctuating asymmetry and the genetic control of developmental stability. Proceedings of the Royal Society B: Biological Sciences, 263: 849-853

Zakharov V.M. (1987) Animal asymmetry: population-phenogenetic approach. Moscow, Nauka, 216 p. (in Russian)

Zhang L., King C.E. (1993) Life history divergence of sympatric diploid and polyploidy populations of brine shrimp Artemia parthenogenetica. Oeclogia, 95: 177-183 